\title{
Metastatic breast cancer suggesting parasitic disease
}

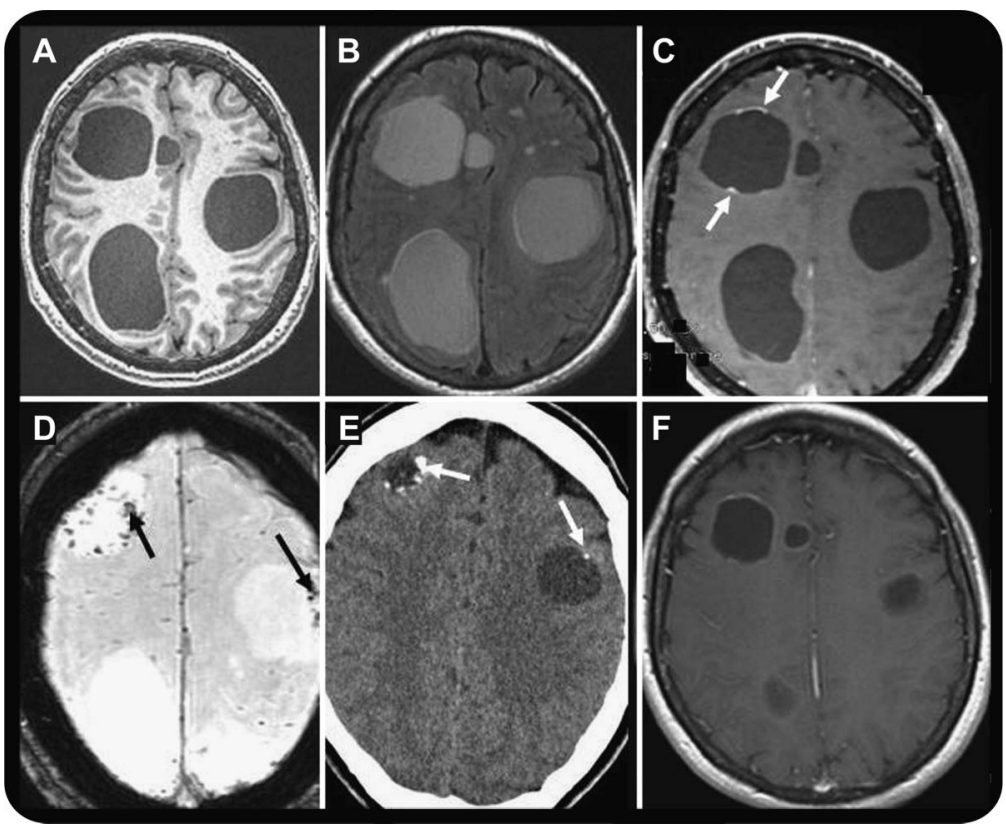

Axial T1-weighted (A), fluid-attenuated inversion recovery (B), and T1 with contrast (C) MRI show multiple cystic intraparenchymal masses with some peripheral enhancement (C). Susceptibility-weighted imaging (D) shows low signal foci (arrows) due to punctate peripheral calcification. These correspond to areas of high density noted on the periphery of cysts on a CT done 6 months prior (E). The CT (E) and T1 with contrast MRI (F) done 6 months prior show interval progression in the size of the cystic masses.

A 62-year-old woman with a history of estrogen-and progesterone receptor-positive metastatic breast carcinoma with extranodal extension, status-post mastectomy and radiation 5 years prior, presented with right focal motor seizures. Neuroimaging and her history of raw meat consumption prompted consideration of neurocysticercosis and hydatid disease. Punctate peripheral calcifications and absence of edema surrounding the minimally enhancing cysts made metastatic breast cancer less likely (figure). However, the increased cyst size over 6 months, rim enhancement, new noncystic pulmonary and skeletal metastasis, and the absence of obvious scolices favored metastatic disease. ${ }^{1,2}$ Surgical decompression yielded yellow fluid. Pathology confirmed the diagnosis of metastatic adenocarcinoma with mammaglobin positivity.

Benjamin L. Bick, MD, Shamir Haji, MD, Ruple S. Laughlin, MD, Robert E. Watson, MD, Neeraj Kumar, MD, Rochester, $M N$

Author contributions: Dr. Bick: image acquisition and draft content contribution. Dr. Haji: draft conceptualization, creation, and revision. Dr. Laughlin: critical revision of the manuscript for important intellectual content. Dr. Watson: critical revision of the manuscript for important intellectual content. Dr. Kumar: critical revision of the manuscript for important intellectual content and study supervision.

The authors report no disclosures relevant to the manuscript. Go to Neurology.org for full disclosures.

Correspondence \& reprint requests to Dr. Kumar: kumar.neeraj@mayo.edu

1. do Amaral LL, Ferreira RM, da Rocha AJ, Ferreira NP. Neurocysticercosis: evaluation with advanced magnetic resonance techniques and atypical forms. Top Magn Reson Imaging 2005;16:127-144.

2. Troiani C, Lopes CCB, Scardovelli CA, Nai GA. Cystic brain metastasis radiologically simulating neurocysticercosis. Sao Paulo Med J 2001;129:352-356. 


\title{
Neurology
}

\author{
Metastatic breast cancer suggesting parasitic disease \\ Benjamin L. Bick, Shamir Haji, Ruple S. Laughlin, et al. \\ Neurology 2012;79;2366 \\ DOI 10.1212/WNL.0b013e318278b696
}

This information is current as of December 10, 2012

Updated Information \& Services

References

Subspecialty Collections

Permissions \& Licensing

Reprints including high resolution figures, can be found at: http://n.neurology.org/content/79/24/2366.full

This article cites 2 articles, 0 of which you can access for free at: http://n.neurology.org/content/79/24/2366.full\#ref-list-1

This article, along with others on similar topics, appears in the following collection(s):

CT

http://n.neurology.org/cgi/collection/ct

Metastatic tumor

http://n.neurology.org/cgi/collection/metastatic_tumor MRI

http://n.neurology.org/cgi/collection/mri

Information about reproducing this article in parts (figures,tables) or in its entirety can be found online at:

http://www.neurology.org/about/about_the_journal\#permissions

Information about ordering reprints can be found online:

http://n.neurology.org/subscribers/advertise

Neurology ${ }^{\circledR}$ is the official journal of the American Academy of Neurology. Published continuously since 1951 , it is now a weekly with 48 issues per year. Copyright @ 2012 American Academy of Neurology. All rights reserved. Print ISSN: 0028-3878. Online ISSN: 1526-632X.

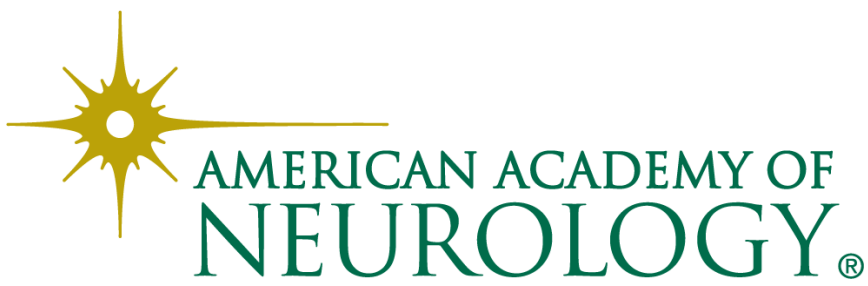

